\title{
A Revolution in Information?
}

\section{Citation}

Blair, Ann, and Devin Fitzgerald. 2014. "A Revolution in Information?" In The Oxford Handbook of Early Modern European History, 1350-1750, edited by Hamish Scott, 244-65. Oxford: Oxford University Press.

\section{Published Version}

doi:10.1093/oxfordhb/9780199597253.013.8

\section{Permanent link}

http://nrs.harvard.edu/urn-3:HUL.InstRepos:34334604

\section{Terms of Use}

This article was downloaded from Harvard University's DASH repository, and is made available under the terms and conditions applicable to Open Access Policy Articles, as set forth at http:// nrs.harvard.edu/urn-3:HUL.InstRepos:dash.current.terms-of-use\#OAP

\section{Share Your Story}

The Harvard community has made this article openly available.

Please share how this access benefits you. Submit a story.

Accessibility 


\section{Manuscript of}

Ann Blair and Devin Fitzgerald, "A Revolution in Information?" in the Oxford Handbook of Early Modern European History, ed. Hamish Scott (Oxford: Oxford University Press, 2015), pp. 244-65.

\section{Chapter 10}

A revolution in information? ${ }^{1}$

Ann Blair and Devin Fitzgerald

The notion of a revolution in information in early modern Europe is a recent historiographical construct, inspired by the current use of the term to designate the transformations of the late 20th century. The notion, first propounded in the $1960 \mathrm{~s}$, that we live in an "information age" crucially defined by digital technologies for creating, storing, commoditizing, and disseminating information has motivated historians, especially since the late 1990 s, to reflect on parallels with the past. ${ }^{2}$ Given the many definitions for "information" and related concepts, we will use the term in a nontechnical way, as distinct from data (which requires further processing before it can be meaningful) and from knowledge (which implies an individual knower). Information typically presents itself as discrete reports of supposedly truthful or useful facts or messages that

${ }^{1}$ We are grateful to Noah Millstone of the volume for very helpful comments and to Reinhard Bodenmann and Eleanor Hubbard for consultations on specific points.

${ }^{2}$ Pioneering uses of the term in early modern contexts include: Robert Darnton, "An Early Information Society: News and the Media in Eighteenth-Century Paris," American Historical Review 105 (2000), 1-35; John J. McCusker, "The Demise of Distance: The Business Press and the Origins of the Information Revolution in the Early Modern Atlantic World," American Historical Review, 110 (April 2005), 295-321; and Michael Hobart and Zachary Schiffman, Information Ages: Literacy, Numeracy and the Computer Revolution (Johns Hopkins University Press, 1998). OED dates "information revolution" to 1961 . 
can travel across time and place by being repeated and appropriated. ${ }^{3}$ Then as now information was conveyed and apprehended in countless combinations of intended and actual audiences, meanings, and effects, and in myriad forms, including gestures, rituals, objects, images, and words--spoken, sung, manuscript, and printed. Some of these elements cannot be recaptured, but many topics crucial to a history of information in the early modern period have been well studied under various auspices: printing and its impact, the growth of literacy and numeracy, the rise of record-keeping (e.g. among merchants, rulers, and scholars), the dissemination and impact of news, the development of a postal network, the circulation of letters, rumors, and secrets. ${ }^{4}$

The transformations in the cultures and technologies of information between 14 th and 18th centuries were considerable and their legacies are still visible today. But these changes were neither sudden nor linear and cannot easily be dissociated from the many other changes that characterized the early modern period. "Revolution" applies only as a metaphor to emphasize the qualitative degree of change in these transformations, not their suddenness or speed. Most of the forms of information we discuss predated the early modern period in some form: reference books, libraries, catalogs and finding devices, institutional, legal, and mercantile record-keeping, and the circulation of news, orally and in writing, through the movements of soldiers and merchants, pilgrims and clerics, noblemen and vagabonds. Late medieval manuscripts could be produced commercially, in large numbers and for rapid distribution, serving functions we typically associate with

\footnotetext{
${ }^{3}$ On the terms "fact" and "data" in this period, see Barbara Shapiro, A Culture of Fact: England 1550-1720 (Ithaca, NY: Cornell University Press, 2000) and Daniel Rosenberg, "Data before the Fact," in Raw Data is an Oxymoron, ed. Lisa Gitelman (Cambridge: MIT Press, 2013),15-40.

${ }^{4}$ The subject of vastly increased information and its implications overlaps with other topics covered in this volume: see especially, James R. Raven, 'Print and Printedness' (chapter 8) and Hamish Scott, 'Travel and Communications' (chapter 7).
} 
printing. In Paris for example in the wake of public disasters like the Black Death of 1348 or the Great Schism (1378-1417), the faculties of medicine and theology published manuscript tractatuli, mini treatises, in a single leaf format designed to be copied and disseminated fast and widely. Jean Gerson, Chancellor of the University of Paris, chose a tractatulus to diffuse his opinion of the victory of Joan of Arc at Orléans on May 8, 1429; his work had reached Rome a few weeks later and we have evidence of its circulation to England and Flanders too. ${ }^{5}$

In the following centuries the volume of information gathered and the speed and extent of its diffusion increased massively, though not always consistently or linearly, due to the combined impact of technological, political, and socio-cultural factors. The rapid growth of information (including mis- and dis-information) created new challenges in accessing, evaluating, and managing it. Indexes, finding devices, numbering systems, lists, and encyclopedias, became common in most fields of knowledge. In commerce and politics information became a commodity that was bought and sold in many forms --oral, manuscript and print-- and information brokers emerged to carry out more or less formally defined duties as intermediaries. By the 18th century diplomats, merchants, colonial administrators, archivists, and librarians, could refer to manuals that systematized their activities even if they were not fully professionalized by modern standards. News which had hitherto been the purview of elites relying on personal channels of information became available in print, starting with pamphlets developed in the first decades of printing, down to the daily newspapers of the 18th century. Letters and printed matter travelled between European cities with remarkable speed thanks to a

\footnotetext{
${ }^{5}$ Daniel Hobbins, Authorship and Publicity before Print: Jean Gerson and the Transformation of Late Medieval Learning (Philadelphia: University of Pennsylvania Press, 2009),128, 150.
} 
postal service in place by the 17 th century that promised delivery in 3-7 days; and people and news circulated across the entire globe on the ships of the merchant companies that expanded Europe's commercial and political reach. ${ }^{6}$

\section{Information in fields of learning}

In 1778 the Anglican essayist Vicesimus Knox praised the new genre of the public lecture which he assimilated to the sermon, observing: "Though books are easily procured, yet even in this age of information, there are thousands in the lower classes who cannot read" and for whom a sermon or lecture was more effective. ${ }^{7}$ Knox's expression "age of information" was unique at the time (and hardly used again until the 20th century), but the English term "information" was not new in itself, in use from the 14th century initially in a narrow sense of instruction, legal report, or intelligence on a particular topic. In keeping with the broadening meaning of the term in the 18 th century Knox equated "information" with the easy availability of books in general, implicitly crediting the cumulative impact of printing. At the same time Knox noted the limited impact of printed matter on the illiterate, and reveals the limits of his own numeracy by our standards. In mentioning "thousands" of illiterates Knox presumably meant to and did convey a sense of "very many," but his figure was a serious underestimate of the number of illiterates at a time when London had a population of close to one million and literacy rates have been estimated at $60 \%$ for men and $40 \%$ for women in England ca 1750 . Even granting that literacy rates in cities were higher than national averages, there were

\footnotetext{
${ }^{6}$ Wolfgang Behringer, "Communications Revolutions: A Historiographical Concept," German History 24:3 (2006): 333-74, 344.

${ }^{7}$ Vicesimus Knox, Essays, Moral and Literary (London: for Edward and Charles Dilly, 1778), vol. 2, p. 157, cited and discussed in Paul Duguid "The Ageing of Information," forthcoming Journal of the History of Ideas.
} 
hundreds of thousands of illiterates in London in the late 18 th century. ${ }^{8}$ Of course illiteracy did not preclude apprehension of written matter which one could hear being cried out in the streets, read aloud and discussed, informally and more formally, including in the public lectures and sermons that Knox hailed as so beneficial.

In the middle ages "literatus" designated someone able to read Latin, a skill which conveyed status and special treatment in a court of law under the "benefit of clergy." ${ }^{9}$ The Oxford English Dictionary dates the weaker modern meaning of "able to read and write" to 1613 . The term is still imprecise today, since reading and writing are different skills designated by a single term. Those two skills are inextricably linked for historians in any case who typically measure ability to read in the past by the ability to sign one's name on an official document such as a registry of marriages or England's Protestation oath in 1641-42. Other, indirect measures of literacy --the only ones ${ }^{10}$ available in the absence of serial records-- include school attendance, book ownership (from inventories after death), or the numbers of books produced, which each pose challenges to persuasive conclusions. Rates of signing remain the most widely used measure of literacy, based on the general conclusion that early modern schools taught reading first then writing. Given this rigid sequence it is possible that some could read who had not yet learned to write or sign their name, but the reverse phenomenon which we see today in young children who can write their name before learning to read is assumed to be uncommon in early modern Europe. "Literacy" is also fraught with ambiguity because it spans a range of reading skills, from the basic or pragmatic literacy

\footnotetext{
${ }^{8}$ John Brewer, The Pleasures of the imagination: English culture in the eighteenth century (London: HarperCollins, 1997), 167-68, 395.

${ }^{9}$ Michael Clanchy, From memory to written record, England, 1066-1307, 3rd ed.
} (Oxford: Blackwell, 2012), 228-32. 
implicit in the occasional use of formulaic written documents to the increasing levels of proficiency required to read printed matter in blackletter, or in roman type, or handwriting. ${ }^{11}$

By any measure literacy rates between the 15 th and 18 th centuries rose dramatically, at least tenfold from an estimated 5\% male literacy rate overall in the late 15 th century to over $50 \%$. Such broad figures mask great variations across social and geographical contexts and periods of stagnant or even declining literacy rates. ${ }^{12}$ More detailed studies can provide figures for specific times and places. A few generalizations are possible here nonetheless: literacy was closely related to wealth and social standing-children from homes which did not require their labor were able to attend school.

Literacy rates were higher in cities where written and printed materials were more commonly available and adults could learn to read from their peers. Male literacy rates were typically twice as high as female rates-- schooling was considered less valuable for girls and in the 16 th century "most of the literate women came from the nobility and upper bourgeoisie." Certain Protestant contexts where reading was valued as an act of piety generated unusually high literacy rates, including near universal literacy achieved by men in 18th-century New England, by English Quakers in 1754, and in Sweden by 1700. ${ }^{13}$ There a Church decree of 1686 mandated annual examinations in each parish; adults who failed the test in reading and knowledge of the Bible were excluded from marriage and communion. As a result families were under great pressure to give their

${ }^{11}$ Keith Thomas, "The Meaning of Literacy in Early Modern England," in Gerd Baumann ed., The Written Word: Literacy in Transition (Oxford: Clarendon, 1986), 97-131.

$12 \mathrm{On}$ areas of stagnation and decline, see David Cressy, Literacy and the social order : reading and writing in Tudor and Stuart England (Cambridge: Cambridge University Press, 1980), chap. 7.

${ }^{13}$ R. A. Houston, Literacy in early modern Europe: culture and education 1500-1800 (London: Longman, 1988), chap. 7, 146 (women), 158 (Quakers). See E. Jennifer Monaghan, Learning to Read and Write in Colonial America (Amherst: University of Massachusetts Press, 2005), 3. 
children the requisite skills and did so even in the absence of schools. In the aggregate literacy levels were often equal between Protestant and Catholic contexts with similar social and urban distributions. ${ }^{14}$

Rising rates of literacy were both fueled by and in turn encouraged the production of books, notably through printing. Already by the mid-16th century the learned complained about an overabundance of books. Jean Bodin observed in 1566 for example that in the field of history alone "the life of a man, however prolonged, is hardly sufficient for reading [all of them]." ${ }^{15}$ Printing was an important proximate cause of the perception of an overabundance of books or multitudo librorum, but the technology does not suffice in itself to explain the uses made of it and the anxieties associated with it. Equally significant was a cultural attitude in the Renaissance which valued saving and stockpiling information of all kinds-- printed books, manuscripts, natural specimens, works of art, or antiquarian remains-- so that overload resulted. Sources of this info-lust or collecting mentality included a culture of display made possible by rising levels of wealth among urban elites, but also Renaissance humanism which generated great interest in all things ancient and at the same time a traumatic awareness of how many ancient texts had been permanently lost. ${ }^{16}$ For example Conrad Gessner composed his Bibliotheca universalis in 1545 listing all known works in Latin and Greek both to aid in finding those works which were still lost and to guard against a devastating loss of texts

\footnotetext{
${ }^{14}$ Houston, 159-60; Cressy, 178; and Egil Johansson, "History of Literacy in Sweden," in Harvey Graff et al. eds., Understanding Literacy in its Historical Contexts: Socio-Cultural History and the Legacy of Egil Johansson (Lund: Nordic Academic Press, 2009), 28-59.

15 "Nihilominus tot ac tam multa restant, ut iis legendis hominum vita quantumvis diuturna, vix sufficere possit." Jean Bodin, Methodus ad facilem historiarum cognitionem, ed. Sara Miglietti (Pisa: Edizioni della Normale, 2013), ch. 2, section 3, p. 104.

${ }^{16}$ On collecting see Paula Findlen, Possessing Nature : museums, collecting, and scientific culture in early modern Italy (Berkeley: University of California Press, 1994); on the perception of overload: Ann Blair, Too Much To Know: managing scholarly information before the modern age (New Haven: Yale University Press, 2010), chap. 1 and 20-22, 64 on awareness of loss.
} 
in the future. Gesner hailed printing as a great help in the conservation of literature for posterity, as long as libraries were funded to preserve the printed books. Gesner acknowledged the "confused and noxious multitude of books" but also opined, quoting the ancient encyclopedist Pliny the Elder, that "there is no book so bad that some good cannot be gotten of it". ${ }^{17}$ Gessner emphasized exhaustive accumulation, including books which could be considered bad, lest any losses be regretted later, just as scholars in his day bemoaned the destruction of ancient texts which were not copied by medieval scribes.

To palliate the overabundance that resulted from a refusal to cull the stock of knowledge, various kinds of reference works excerpted or summarized the many other books one did not have the resources to buy or the time to read oneself. Latin florilegia, commonplace books and, after 1680, collections of book reviews, and dictionaries of arts and sciences in the vernaculars were all successful genres (even when they were large and expensive) which spread familiarity with alphabetized entries and indexes, tables of contents, and organizational charts (such as the branching diagrams made by followers of Peter Ramus in the 16th century and still favored by d'Alembert in the preliminary discourse to the Encyclopédie). ${ }^{18}$ While humanism drove the accumulation of texts from and about antiquity, similar explosions of information occurred in almost every field of learning. Especially spectacular in natural history were the impact of reports of voyages to exotic lands and a new attention to the flora and fauna of familiar places. Starting in the late 16 th century universities each competed to found a botanical garden, and for plants that were too difficult to cultivate, collections of dry specimens. In 1630 the best

\footnotetext{
${ }^{17}$ Conrad Gesner, Bibliotheca universalis (Zurich: Froschauer, 1545), sig. 3r-v.

${ }^{18}$ Blair, chap. 3 .
} 
botanical work cataloged 6000 plants whereas only 80 years earlier the most comprehensive work of botany was an edition of the Greek Dioscorides with 500 specimens. $^{19}$

Across most areas of learning (e.g. astronomy, antiquarianism, natural history, philology in multiple languages, and even the more secretive field of alchemy) scholars exchanged, gathered, and compared information through large and overlapping correspondence networks. Thousands of letters to hundreds of correspondents survive for countless learned men all over Europe, from Johannes Kepler in Prague to Henry Oldenburg in London, from Erasmus in the early 16th century to Voltaire in the 18th. ${ }^{20}$ Letters spread information of different kinds: personal observations and conclusions, bibliographical references, and reports from others relevant to the interests shared by the two correspondents, but also general political news (including local events and rumors, or fears of war, for example) and personal news about family and friends. Letters were often designed for further circulation by the addressee. For example correspondents to the Zurich reformer Heinrich Bullinger generally wrote in Latin but used German for passages which they asked Bullinger to read out loud to the city councillors (who knew no Latin), in the hope of swaying the city's policy. ${ }^{21}$ Scientific or political news received by letter would be recirculated in other letters. Sometimes this circulation could extend beyond the circle of friends, with dangerous consequences. A letter that René Descartes sent to a friend discussing his interpretation of the Eucharist was sent on once too often

\footnotetext{
${ }^{19}$ Brian Ogilvie, "Encyclopaedism in Renaissance Botany: from Historia to Pinax," in Peter Binkley Premodern encyclopaedic texts: proceedings of the second COMERS congress, Groningen, 1-4 July 1996 (Leiden: Brill,1997), 89-99.

${ }^{20}$ See Christiane Berkvens-Stevelinck, Hans Bots and Jens Häseler eds., Les grands intermédiaires culturels de la République des Lettres: études de réseaux de correspondance du XVIe au XVIIIe siècles (Paris: Champion, 2005) and the digital project underway: http://republicofletters.stanford.edu/

${ }^{21}$ Heinrich Bullinger, Briefwechsel, vol. 15: Briefe des Jahres 1545, ed. Reinhard Bodenmann et al. (Zurich: Theologischer Verlag, 2013), e.g. letters 2016, 2313
} 
when it ended in the hands of an indignant Jesuit who precipitated the posthumous condemnation of Descartes's views by the Catholic Church. ${ }^{22}$ Letters reached beyond the succession of personal contacts when collections of a scholar's letters were printed, by himself, or posthumously by intellectual or genealogical heirs. These letters were typically edited before publication to remove material considered too personal or sensitive. $^{23}$

The Republic of Letters (respublica literarum) was a term in use from at least the 16th century to designate the community formed by the circulation through print, letter, travel, and conversation on many topics, with the ideal of transcending differences of national origin and religious affiliation in the shared pursuit of learning. In practice individual and national rivalries and religious differences shaped these interactions too, and the Republic was also more diverse than its self-image suggested, including a network of women who found support from one another in and from the court of Elizabeth of Bohemia in exile in the Hague from the 1630s. ${ }^{24}$ At first this Republic operated in Latin, even among scholars who shared a common vernacular, because the vernaculars were thought to lack the precision of expression and richness of vocabulary

\footnotetext{
${ }^{22}$ Tad Schmaltz, Radical Cartesianism: the French reception of Descartes (Cambridge: Cambridge University Press, 2004), 40 note 49.

${ }^{23}$ For example Erasmus published over one thousand of his letters in 21 different collections in his lifetime; for a study of how he edited them see Léon-E Halkin, Erasmus ex Erasmo (Aubel: Gason, 1983). One scholar estimates that over 40,000 letters had been printed in Italy by 1627; Amedeo Quondam, Le Carte messaggiere: retorica e modelli di communicazione epistolare per un indice dei libri di lettere del Cinquecento (Rome: Bulzoni, 1981), 35. On collections published by contemporaries see Hans Bots and Françoise Waquet, La République des Lettres (Paris: Belin, 1997), 151-52, 172-73.

${ }^{24}$ For an entry into this literature see Anthony Grafton, "A Sketch Map of a Lost Continent: The Republic of Letters," Republics of Letters: A Journal for the Study of Knowledge, Politics, and the Arts 1:1 (2009): http://arcade.stanford.edu/rofl/sketch-map-lost-continent-republic-letters\#_ftn7 More recently: Carol Pal, Republic of Women: Rethinking the Republic of Letters in the 17th century (Cambridge: Cambridge University Press, 2012); and, on religious tensions, Ian Maclean, Scholarship, Commerce, Religion: the learned book in the age of confessions, 1560-1630 (Cambridge, Mass: Harvard University Press, 2012).
} 
necessary for philosophical, theological, or scientific discussions. ${ }^{25}$ Through the efforts of vernacular literary authors, the support of princely patrons, the formation of academies and other institutions that bypassed the Latin culture of the universities, by the end of the seventeenth century many vernaculars had become established as languages of learning, with French commonly serving as a lingua franca among scholars who did not share a native language. The first learned periodicals founded in the late 17 th century to circulate news and opinions about recent publications were mostly in the major vernaculars, with the Acta Eruditorum as the principal Latin holdout. This linguistic splintering soon spawned periodicals devoted to reporting on publications in foreign languages, like the Bibliothèque britannique which reported in French on recent English publications. ${ }^{26}$

The decline of Latin occurred later in some places and some fields (e.g. in Germanic, Central European and Nordic parts of Europe, and in the higher faculties of law, medicine, and theology), but throughout Europe the rise of the vernaculars by the 18th century had eroded the boundaries between those learned in Latin and those not, creating a much broader audience for informational writings of all kinds. In the meantime informational genres in the vernacular, which already existed in late Middle Ages, had grown massively in many different genres and across a broad spectrum of learning. Almanacs containing calendrical and basic household and medical advice were printed in enough copies for $40 \%$ of all the households in England. ${ }^{27}$ School primers, works of popular piety, and medical advice were best-selling genres in cheap formats, whose low survival rates today attest to their having been used unto destruction. How-to manuals

\footnotetext{
${ }^{25}$ On the uses of Latin in this period see Brill's Encyclopedia of the Neo-Latin World, ed. Philip Ford, Jan Bloemendal and Charles Fantazzi, 2 vols (Leiden: Brill, 2014).

${ }^{26}$ For an entry into scientific and learned journals see Thomas Broman, "Criticism and the Circulation of News: the Scholarly Press in the late seventeenth century," History of Science 51:2 (2013): 125-50.

${ }^{27}$ Houston, Literacy, 126.
} 
offering tips in activities from gardening to fencing, from letter-writing to cooking, ran the gamut from inexpensive, with woodblock illustrations, to expensive with copper-plate engravings. The uses to which they were put were not necessarily straightforward: a letter-writing manual could appeal to some readers not for its information but for the depiction it provided of fashionable society to those who did not participate in it. ${ }^{28}$ Manuscript remained an essential tool for the dissemination of vernacular information too, through letters, but also the sharing of medical recipes which many noble and educated women collected in notebooks for the use of their families and female heirs. ${ }^{29}$

Information in government, commerce, and empire

During the early modern period institutions of government, church, and commerce played a central role in generating information through increased and new forms of record-keeping.

Governments sought to quantify social phenomena in new ways. Already in the middle ages taxation and mustering soldiers for war required a basic account of population and property. For example the Domesday book commissioned by William the Conqueror in 1086 surveyed the landholdings of the England he had just conquered, but it remained a unique document which was neither updated nor imitated. The arrival of the plague in mid-14th century motivated numerical tallies of the dead in Italian city states; the impacts of war and famine were also bemoaned by contemporary writers in numerical

\footnotetext{
${ }^{28}$ Roger Chartier, Alain Boureau, and Cécile Dauphin, Correspondence: Models of Letter-writing from the Middle Ages to the Nineteenth Century, tr. Christopher Woodall. (Princeton: Princeton University Press, 1997), 97-100.

${ }^{29}$ See Alisha Rankin, Panaceia's Daughters : noblewomen as healers in early modern Germany (Chicago: University of Chicago Press, 2013).
} 
terms, to good rhetorical effect even if the numbers were not accurate. ${ }^{30}$ In early sixteenth-century London an outbreak of plague first motivated systematic bills of mortality which then became standard, with weekly and annual compilations available in print. These formed the data for John Graunt's 1662 Observations on the bills of mortality which offered the first statistical study of the city's population.

During the 17th century the English government initiated other quantitative surveys --of the poor and the cost of maintaining them, of the population or property of various colonies (in Ireland and America), of the balance of trade, or the distribution of wealth for taxation purposes. The results were typically haphazard, based on extrapolation from a small amount of data or out of date information (for example the survey of wealth conducted by the early Tudors was still in use in mid-17th century). Furthermore the quantitative information never actually formed the basis of decisions about governance; Paul Slack concludes that in 17th-century England political factors rather than any numerical evidence determined decisions. ${ }^{31}$ Some were eager to base policy on numerical evidence (like William Petty), while others worried about "reducing policy to numbers." ${ }^{32}$ More generally, throughout Europe few rulers were both able and willing to investigate their accounts and balance them by living within their revenues. ${ }^{33}$ Nonetheless in the 18th century political economy grew from the conviction that quantitative information about commerce and population was crucial to good governance,

\footnotetext{
${ }^{30}$ See John Gagné, "Counting the Dead: Traditions of Enumeration and the Italian Wars," forthcoming Renaissance Quarterly 67:3 (2014).

${ }^{31}$ Paul Slack, "Government and Information in Seventeenth-Century England," Past \& Present 184 (2004): $33-68$

${ }^{32}$ William Petty as quoted in Keith Thomas "Numeracy in Early Modern England," Transactions of the Royal Historical Society, 5th ser., 37 (1987): 103-32, p. 131; John Aubrey as quoted in Slack, 64.

${ }^{33}$ Jacob Soll, The Reckoning: financial accountability and the rise and fall of nations (New York: Basic Books, 2014).
} 
even if those outside government were often more interested in these results than those within it.

The rise of governmental counting was made possible by the spread of more efficient accounting and popular numeracy. Numeracy is even more problematic to define and measure than literacy, since basic counting is treated as part of normal cognitive function; counting beyond 20 and the manipulation of the arithmetic operations typically require instruction and can serve as a minimal definition of numeracy. While historians have not attempted to provide percentages in the same way, it is clear that numeracy lagged behind literacy, growing substantially only in the 18th century when arithmetic first started to be included in ordinary elementary education. ${ }^{34}$ Before then arithmetic was taught in commercial schools attended by those seeking to become merchants, navigators, or surveyors; gentlemen gradually realized the importance of these skills, also for military purposes, and could hire private instructors. The discipline of arithmetic was still new since European trade made the transition to Arabic numerals from Roman numerals and calculations by abacus only between 1450 and 1550. Though Arabic numerals were widely known from the 13th century on, alternatives were in use into the seventeenth century, including the practice of keeping scores with marks on a chalkboard or by counting beans. ${ }^{35}$ At the high end the use of Arabic numerals was crucial to Italian and German bankers like the Fuggers who mastered international banking, using tools like double-entry bookkeeping first described in writing by the Italian Luca Pacioli in $1494 .^{36}$

\footnotetext{
${ }^{34}$ Houston,164. Age-heaping or the tendency to round off numbers has also been used as a measure of low numeracy: Jörg Baten, Dorothee Crayen, and Kerstin Manzel "Zahlenfähigkeit und Zahlendisziplin in Nord- und Westdeutschland, 16.-18. Jahrhundert," Jahrbuch für Wirtschaftsgeschichte 49: 2 (2008): $217-$ 229.

${ }^{35}$ Thomas, "Numeracy," 118-19.

${ }^{36}$ Jane Gleeson-White. Double Entry: how the merchants of Venice created modern finance (New York: Norton, 2012).
} 
More ordinary merchants used numbers to honor contracts but rarely balanced their books and businesses could founder from a basic lack of understanding of their financial situation. ${ }^{37}$ In the 16th century printed handbooks of arithmetic explained the four operations and the "Rule of three" (or proportionality) but in convoluted ways. A plethora of different units and divisions (for money, distance, volume, and weight) complicated reckoning, and attempts at reform foundered on the strength of local custom and identity. At the level of daily life ordinary men and women clearly managed their personal finances, and marginal notes in many books include sums and other arithmetic operations. ${ }^{38}$ It was not considered unusual for women to be numerate. In 18 th-century kitchens, for example, cooks (who were more often women than men except in the greatest households) were expected to keep written tallies of their expenditures and supplies in order to reassure their employers of their honesty, since they were also well placed to skim off items from the pantry for their personal gain. ${ }^{39}$ In a big commercial center like London the activities of mathematical practitioners, who were self-taught or educated at commercial schools, proved an important link between a vernacular mercantile culture and a Baconian program of collaborative investigation into nature. ${ }^{40}$ This context and the demand for aids to arithmetic fueled a number of useful inventions, such as logarithms (John Napier, 1614), the slide rule (William Oughtred, ca. 1622), and calculating machines, such as the one Blaise Pascal devised in 1642 to help his father in

\footnotetext{
${ }^{37}$ Patricia Kline Cohen, A Calculating People: The spread of numeracy in early America, (Chicago, 1982), $18,19-23,28$.

${ }^{38}$ Kathryn James, "Reading numbers in early modern England," BSHM Bulletin: Journal of the British Society for the History of Mathematics 26:1 (2011): 1-16.

${ }^{39}$ Sean Takats, "Domestic Expertise: Literacy and Numeracy in the Eighteenth-Century Kitchen," Proceedings of the Western Society for French History 32 (2004), 46-64.

${ }^{40}$ E.G.R. Taylor, Mathematical practitioners of Tudor and Stuart England (Cambridge University Press, 1967); Deborah Harkness, The Jewel House: Elizabethan London and the Scientific Revolution (New Haven: Yale University Press, 2007).
} 
his duties as tax collector in Normandy, which was then made available for sale in small numbers.

Among the learned disciplines mathematics gained new status in the late sixteenth century from its position as an ancillary field in the medieval hierarchy of the university, thanks to new claims about the unique kind of certainty offered by quantification. Natural philosophers like Christopher Clavius, Galileo, Kepler, and Descartes, emphasized the role of mathematics in astronomy, physics, and the "mixed mathematical" disciplines. They were motivated in their quest for mathematical laws of nature by the biblical assertion that God had "ordered all things in measure, and number, and weight" (Wisdom of Solomon 11:20). Newton's Principia of 1687 confirmed this confidence in mathematization. Although few readers could follow the steps of his mathematical proofs by infinitesimal calculus, Newton used just three laws of motion to explain the movements of every object in the universe, from faraway planets to the phenomena of everyday life. Newton's laws marked the culmination of a century of efforts to devise a physics that could replace Aristotelianism and make sense of Copernicus' heliocentric theory of 1543 . The new physics was a mathematized discipline that inspired attempts to mathematize other disciplines in the following centuries, including various aspects of statecraft; it was also informed by astronomical observations from around the world, made possible by European global expansion for religious, commercial, and imperial purposes. $^{41}$

Not all information-gathering by governments and churches was quantitative. The Reformation and Counter-Reformation churches developed the first qualitative

41 Simon Schaffer. "Newton on the Beach: the Information Order of Principia Mathematica." History of Science 47 (2009) 243-76. 
questionnaires, administered orally, in manuscript, or in print, to measure the effectiveness of religious reform. The English census of communicants of 1676, for example, served as a poll of religious opinion, though James II disregarded the evidence it provided that his policies would not be well received. The questionnaire became a versatile and widely used tool for collecting information for state and church administrations as well as scholarly research. ${ }^{42}$ In France Jean-Baptiste Colbert initiated tax reforms and mercantile policies based on extensive gathering of information from many sources, but after his brief tenure as chief minister, the French crown discontinued most of his initiatives. Colbert started a survey of arts and trades in the country which produced images and descriptions which served as sources for Diderot's Encyclopédie of 1751. Most successfully, he employed a network of archival researchers to find documents that Louis XIV could use to justify his policies, including his claim to the régale (the right to collect the revenues of a bishopric or archbishop during a vacancy and to appoint to benefices in its gift) and to seize cities outside the French border which had once been French. ${ }^{43}$ Archives in which documents were not only stored but also retrievable were increasingly understood to be vital tools of government. ${ }^{44}$ Imperial expansion generated new methods and motives for collecting and using information and the overseas trading companies created structures for trading information as well as goods. The expansion of European trade along global routes, including the discovery of the Americas, resulted in the production of information that vacillated

\footnotetext{
42 Slack, 45-46; and Adam Fox, "Printed Questionnaires, Research Networks and the Discovery of the British Isles 1550-1800," The Historical Journal 53:3 (2010): 593-621.

${ }^{43}$ Jacob Soll, The Information Master: Jean-Baptiste Colbert's secret state intelligence system (Ann Arbor: University of Michigan Press, 2009).

${ }^{44}$ Markus Friedrich, Die Geburt des Archivs: eine Wissensgeschichte (Munich: Oldenbourg, 2013); Randolph Head, "Knowing Like a State: The Transformation of Political Knowledge in Swiss Archives, 1450-1770," Journal of Modern History 75: 4 (2003): 745-782.
} 
between the poles of classified and open. Royal Spanish cosmographers exemplified the practical application of advances in mathematics and humanism as well as the secrecy demanded by their state. Calling upon classical works such as Ptolemy's Geography, they produced sophisticated ethnographic and geographic descriptions of the new territories conquered by the Iberian empires. Cosmography became a key component of Hapsburg colonial state-craft, and state sponsorship of cosmographical projects boomed under the patronage of Philip II. ${ }^{45}$ The charts and reports produced by cosmographers using material from the Americas were initially closely guarded by the Spanish crown. During the sixteenth century, the Reformation and anti-Hapsburg struggles throughout Europe led Philip II to classify all information that could be used against his massive empire. Despite his best efforts to control information flows from the center of his "spider's web," information leaked or, as in the case of Aztec painted Manuscript Codex Mendoza, was captured at sea to eventually be purchased by interested parties, in that case, the Englishman Richard Hakluyt. ${ }^{46}$

Unlike the Spanish expeditions, English colonial ventures were not run directly by the Crown, but through letters patent granted to individuals and companies. Richard Hakluyt (1553-1616) was among the first to argue for the importance of empire to the survival of England. Hakluyt watched the Spanish expand, read of French exploration in

\footnotetext{
${ }^{45}$ See María M. Portuondo, Secret Science: Spanish Cosmography and the New World. (Chicago: University of Chicago Press, 2009); Klaus A. Vogel, "Cosmography," in Katharine Park, and Lorraine Daston eds. The Cambridge History of Science: Vol. 3: Early Modern Science (Cambridge: Cambridge University Press, 2008), 469-496.

${ }^{46}$ See Cristina Borreguero Beltran, "Philip of Spain: The Spider's Web of News and Information" in Brendan Dooley ed., The Dissemination of News and the Emergence of Contemporaneity in Early Modern Europe (Farnham, Surrey: Ashgate, 2010), 23-50. Richard Hakluyt (1553-1616) purchased the Codex Mendoza in France from the cosmographer André Thévet, another traveler-cum-author busily collecting materials on the New World. See P.T. Hajovsky, "André Thevet's 'true' Portrait of Moctezuma and Its European Legacy," Word and Image 25:4 (2009): 335-352.
} 
Canada, and dedicated his life to advocating for the English exploration of America. He gathered information about recent voyages and explorations, publishing translations of foreign language accounts, and disseminated geographical information to an eager public seeking both pleasure and profit. ${ }^{47}$ His accounts became indispensable guides for travelers from England: companies gave copies of his works to merchants planning to go abroad. $^{48}$

Other global travellers who reported on exotic locations included Catholic missionaries from many orders. The Jesuits, who established houses across the globe from Southeast Asia and China to Canada and Latin America, were especially careful about managing reports sent annually to Rome from the foreign missions; they could be consulted and shared both within and outside the order or published in edited form. ${ }^{49}$ The Jesuit relations from New France, published annually starting in 1632 fostered an appreciative audience and callings like that of Marie de l'Incarnation who dreamed of martyrdom when she left France for Quebec to help establish the Ursuline order there. More generally the travel narrative had become a best-selling genre across Europe by the late 17 th century, exposing readers to beliefs and social practices from around the world,

\footnotetext{
${ }^{47}$ See Peter C Mancall, Hakluyt's Promise: An Elizabethan's Obsession for an English America (New Haven: Yale University Press, 2007); David Armitage, The Ideological Origins of the British Empire (Cambridge: Cambridge University Press, 2000), 72-81. See also Nicholas Popper, Walter Ralegh's History of the World and the Historical Culture of the Late Renaissance (Chicago: University of Chicago Press, 2012).

${ }^{48}$ Alison Games, The Web of Empire: English Cosmopolitans in an Age of Expansion, 1560-1660 (Oxford: Oxford University Press, 2008), 21.

${ }^{49}$ Florence Hsia, Sojourners in a Strange Land: Jesuits and their scientific missions in late imperial China (Chicago: University of Chicago Press, 2009); Markus Friedrich, Der lange Arm Roms? Globale

Verwaltung und Kommunikation im Jesuitenorden 1540-1773 (Frankfurt: Campus Verlag, 2011).
} 
fostering a new awareness of cultural difference and in some cases admiration for the "noble savage." 50

The great engines of colonial expansion outside Iberia were the trading companies formed by wealthy merchants pooling resources to undertake high-risk commercial expeditions. The first of these, the East India Company chartered in 1600 by Elizabeth I, negotiated the status of trading posts throughout South Asia as small extraterritorial bases where the Company performed the functions of government, and waged battles with rival ships as needed in order to protect its trade routes. ${ }^{51}$ The Dutch East India Company (Vereenigde Oostindische Compagnie or VOC) operated as a private company with close ties to the ruling elites in Amsterdam. Although the company was famous for its lack of interest in anything but profits, its regular voyages to the East Indies generated information about the people, places, plants, and goods they encountered on land and sea (including other European powers). ${ }^{52}$ Above all the information about prices and commodities brought back from VOC ventures combined with political news flowing in from diplomatic sources and the loose observation of policies about secrecy made Amsterdam-- also located at the center of Europe trade routes from the Baltic and Rhineland corridor-- into a crucial information hub. Information was shared face to face,

\footnotetext{
${ }^{50}$ Anthony Pagden, European Encounters with the New World: from Renaissance to Romanticism (New Haven: Yale University Press, 1993).

${ }^{51}$ Philip J. Stern, The Company-State. Corporate Sovereignty and the Early Modern Foundation of the British Empire in India (Oxford: Oxford University Press, 2011).

${ }^{52}$ Siegfried Huigen Jan L. Jong, and Elmer Kolfin eds. The Dutch Trading Companies As Knowledge Networks (Leiden: Brill, 2010), e.g. 8. Harold J Cook, Matters of Exchange: Commerce, Medicine, and Science in the Dutch Golden Age (New Haven: Yale University Press, 2007). For more critical views of the encounter with the New World see Walter Mignolo, The Darker Side of the Renaissance: Literacy, Territoriality, and Colonization (Ann Arbor: University of Michigan Press, 2003) and Joyce E. Chaplin Subject Matter: Technology, the Body, and Science on the Anglo-American Frontier, 1500-1676 (Cambridge, Mass: Harvard University Press, 2001).
} 
and through brokers who traded in information notably at the Amsterdam Exchange which served as an early stock market; some information was also printed in newspapers and merchant handbooks. The VOC also drew on its accumulating stock of records to estimate future prices and demand patterns for different commodities. This aggregate information spread beyond the closed meetings of the Company. Though the VOC declined in the 18th century, the techniques of information recording and aggregation remained a central part of capitalism thereafter. ${ }^{53}$

News

Crucial to these developments in commerce, government, and empire-building, but also to the rise of literacy, was the increased speed, geographical reach, and quantity of the news in early modern Europe. Reliable information about recent events presented as new (or "news") had long been of great moment for those making commercial, military or political decisions. In the middle ages news conveyed by word of mouth or by letter could be fast and accurate, but few could afford such service. ${ }^{54}$ In the early modern period printing and improved routes of communication made possible an explosion of news, resulting in variety of different genres and new kinds of employment to collect and distribute the news, and in new political debates about communication and secrecy and, by the 18 th century especially, public opinion. ${ }^{55}$

\footnotetext{
${ }^{53}$ The classic study of business information is Woodruff D. Smith, "The Function of Commercial Centers in the Modernization of European Capitalism: Amsterdam as an Information Exchange in the Seventeenth Century," The Journal of Economic History. 44:4 (1984): 985-1005.

${ }^{54}$ C. A. J. Armstrong, "Some Examples of the Distribution and Speed of News in England at the Time of the Wars of the Roses," in R.W. Hunt, W.A. Pantin and R.W.Southern eds., Studies in Medieval History: presented to Frederick Maurice Powicke (Oxford: Oxford University Press, 1948), 429-54.

${ }^{55}$ The literature on the news is vast; see especially Andrew Pettegree, The Invention of News: how the world came to know about itself (New Haven: Yale University Press, 2014) and Brendan Dooley ed., The
} 
Oral news networks predated and sustained the circulation of information during the early modern period. ${ }^{56}$ Monarchs issued proclamations which were disseminated by licensed criers, in a practice that continued through the early modern period. Rituals, such as a mass of thanksgiving for the birth of an heir, were also used by kings to convey news. Louis XIV for example used Te Deum masses to announce his military victories. ${ }^{57}$ But oral and ceremonial news were increasingly complemented by news circulated in manuscript and in print, generated by merchants and states, and by printers seeking profit from the broad sale of a cheap imprint. "News" included misinformation and disinformation too. For example news reports of the destitution triggered by the crash of the tulip bubble had little foundation in reality; the news licensed by rulers and institutions under their sway was often closer to propaganda. ${ }^{58}$

For merchants, information guided investments. Antonio Morosini (1365-1434), a Venetian historian and merchant active in the early fifteenth century, received and sent information to business connections throughout the Mediterranean, including Alexandria. He shared news and received news in turn, working much of this information into his scholarly writing. His contemporary, the Prato Merchant Francesco Datini (1335-1410) received over 150,000 letters from informants all over Europe. Merchants maintained extensive networks of correspondence, and during the unstable early modern period,

Dissemination of News and the Emergence of Contemporaneity in Early Modern Europe (Farnham, Surrey: Ashgate, 2010).

${ }^{56}$ See for example Rosa Salzburg and Massimo Rospocher, "Street singers in Italian Renaissance urban culture and communication," Cultural \& Social History 9:1 (2012): 9-26; more generally Adam Fox, Oral and Literate Culture in England, 1500-1700 (Oxford: Clarendon Press, 2000).

${ }^{57}$ Michèle Fogel, Les cérémonies de l'information dans la France du XVIe au milieu du XVIIIe siècle (Paris: Fayard, 1989).

${ }^{58}$ Anne Goldgar, Tulipmania: money, honor and knowledge in the Dutch Golden Age (University of Chicago Press, 2007). 
business, like governance, was becoming increasingly competitive. Obtaining more reliable information faster emerged as one the best ways to stay ahead of rivals. ${ }^{59}$

Concurrent with the intensification of mercantile correspondence networks, states established new methods for organizing their international relations and gathering information from abroad. During the middle ages, ideas of state sovereignty were relatively inchoate and relations between princes were procedurally informal and often focused on symbolic rituals. During the renaissance, new forms of international relations set the stage for the emergence of early modern diplomacy. ${ }^{60}$ After the papacy withdrew to Avignon in 1309 , the power vacuum left in the Italian peninsula led to intense military rivalry between Italian states, in which survival often depended on knowing the plans of 'allies' and enemies alike. Instead of relying on medieval legates dispatched to send specific messages, the Renaissance Italian city-states created professional ambassadors posted as permanent representatives of the state abroad. The special mission of ambassadors was to provide a continual flow of information. While ambassadors were in residence, they cultivated relationships meant to increase their effectiveness as information gathering agents - spies, merchants, and ranking nobility. By providing regular, even daily, updates on political news, ambassadors gave their states the information they needed to protect their interests domestically and internationally.

Ambassadors were also essential to managing relationships with foreign powers. Venice is perhaps most famous for the reports produced by its early ambassadors on the

${ }^{59}$ Georg Christ, "A Newsletter in 1419? Antonio Morosini's Chronicle in the Light of Commercial Correspondence Between Venice and Alexandria," Mediterranean Historical Review 20:1 (2005) 35-66; Mario Infelise, "News Networks Between Italy and Europe," in Dooley, The Dissemination of News, 51-67.

${ }^{60}$ See Garrett Mattingly, Renaissance Diplomacy (New York, NY: Dover 1988 [first published 1955]) and Daniela Frigo, Politics and Diplomacy in Early Modern Italy: The Structure of Diplomatic Practice, 14501800 (Cambridge, UK: Cambridge University Press, 2000). 
Ottoman Empire. Beginning in 1454, Venice installed a permanent ambassador in

Istanbul, the bailo, who maintained a large network of informants in the Ottoman capital, gleaning information from other consulates, expatriate Europeans, translators (called dragomans), and Ottoman subjects. Upon returning to Venice, they would augment their regular dispatches by delivering a summarizing document known as relazioni. ${ }^{61}$ By the late fifteenth century, information gathering was a regular part of ambassadorial duties. One Genoese author noted that "spying on the designs and secrets of princes is the very trade of ambassadors, and especially residents." The volume of material produced by ambassadors abroad was impressive. One Venetian diplomat in Rome sent over 400 dispatches, some long and others brief, over just twelve months. ${ }^{62}$ To handle this influx of information, states had to improve archiving practices and expand their bureaucracies. ${ }^{63}$ Over the course of the early modern period, Italian-style diplomacy became the standard for the whole of Europe. By the sixteenth century, nearly every state benefitted from spies and diplomats working to further their interests. ${ }^{64}$ Though diplomatic information was meant to be secret (and was sometimes encrypted), it could

${ }^{61}$ See Donald E. Queller, "The Development of the Ambassadorial Relazioni," in J.R. Hale ed., Renaissance Venice (London: Faber and Faber, 1974); and Eric Dursteler, "The Bailo in Constantinople: Crisis and Career in Venice's Early Modern Diplomatic Corps," Mediterranean Historical Review 16:2 (2001): 1-30. On relations with the Ottomans, see Garrett Mattingly, Renaissance Diplomacy; Daniel Goffman, "Negotiating with the Renaissance state: the Ottoman Empire and the new diplomacy," in Virginia Aksan and Daniel Goffman eds., The Early Modern Ottomans: Remapping the Empire (Cambridge: Cambridge University Press, 2007), 61-74; and E. Natalie Rothman "Interpreting Dragomans: Boundaries and Crossings in the Early Modern Mediterranean," Comparative Studies in Society and History 51: 4 (October 2009): 771800.

${ }^{62}$ Mattingly, Renaissance Diplomacy, 96; Andrea Spinola quoted in Dursteler, 'Bailo', 3.

${ }^{63}$ Paul Dover, "Deciphering the Diplomatic Archives of Fifteenth-Century Italy," Archival Science 7:4 (2007), 297-316; Filippo de Vivo, "Ordering the archive in early modern Venice 1400 to 1650," in Archival Science 10:3 1(2010): 231-48.

${ }^{64}$ For further diplomatic contexts see Robyn Adams, and Rosanna Cox, Diplomacy and Early Modern Culture (Houndsmills: Palgrave Macmillan, 2011). 
be leaked and transformed at any stage of gathering and transmission by the many agents involved. Once it arrived at destination, the Venetian government by an oligarchic senate was especially secretive, but political insiders also used leaks to achieve political goals, by spreading secrets within the ruling elite and more occasionally to the broader public. ${ }^{65}$ Diplomatic letters and reports were all manuscript. So too were the first regular news-sheets for sale or avvisi. The avvisi were couched as personal letters containing recopied portions of correspondences, diplomatic reports, and hearsay, but they were produced in multiple copies for the closely intertwined political and mercantile information networks of the Italian peninsula. The genre emerged gradually over the course of the fifteenth century, and also reached clients spread across Europe. The Florentine Merchant Benedetto Dei (1418-1492) was one of the first to market newsletters for profit. After traveling extensively throughout Europe and North Africa, Dei began sending news to his numerous contacts for a small subscription fee. The news extracts were brief, and catered to the general interests of a wide readership, as the example from 1478 below illustrates:

I have news from Genoa that the Doge has knighted Batistino and sent away the [families of] Adorini and Raonesi

I have news from Lyon, the trade fair has been very good; a lot of textiles have been sold and a good deal of money gained too

\footnotetext{
${ }^{65}$ Filippo de Vivo, Information and Communication in Venice. Rethinking Early Modern Politics (Oxford: Oxford University Press, 2007). On the rise of agents, see Hans Cools, Marika Keblusek and Badeloch Noldus, Your Humble Servant: Agents in early modern Europe (Hulversum, The Netherlands: Uitgeverij Verloren, 2006).
} 
I have news from France that nine ambassadors are coming to Italy with 200 horses to make peace for everyone. ${ }^{66}$

Dei's early manuscript newsletters circulated by subscription coincided with the first event to be reported in print almost contemporaneously with its occurrence-- the Turkish sack of Negroponte in 1470.

The Aegean island of Negroponte held out for months before the Turks finally broke through its walls while a fleet of Venetian ships looked on. After entering the city, Turkish soldiers killed every male over the age of fifteen. The bloody massacre of Negroponte shocked Italy and Europe, conjuring the phantom of Ottoman invasion. News of the event circulated through the peninsula first through correspondence and oral networks. By 1472, at least twelve printed accounts of the event were marketed to audiences in both vernacular and polished humanist Latin. The shock of Negroponte's fall captured public attention at every level, provoked responses that crossed the boundaries of language and genre, and set the close-knit worlds of Italian humanism, diplomacy, and book-publishing into productive motion. Printing did not create these reactions, nor make them possible; instead the well-established networks of information circulation in manuscript, provided a fertile environment for the circulation of these early printed pamphlets. ${ }^{67}$ Pamphlets about Negroponte were not intended to convey new information about events to an otherwise ignorant public. Instead, the pamphlets were laden with polemical intentions, some were meant to raise support for a crusade and

\footnotetext{
${ }^{66}$ Quotation from Mario Infelise, "From merchants' letters to handwritten political avvisi," in Francisco Bethencourt and Florike Edmond eds., Cultural Exchange in Early Modern Europe, vol 3, Correspondence and Cultural Exchange in Europe, 1400-1700 (Cambridge: Cambridge University press, 2007), 39.

${ }^{67}$ Meserve, Margaret. "News from Negroponte: Politics, Popular Opinion, and Information Exchange in the First Decade of the Italian Press," Renaissance Quarterly 59:2 (2006): 440-480.
} 
others were meant to memorialize or blame participants in the city's fall. Unlike avvisi, which were produced and circulated on a regular schedule, pamphlets were produced in response to major events and controversies in places where a market for printed matter was already established.

The circumstances needed to sustain the production of printed news could prove shortlived. For example the port city of Rouen, Normandy briefly became a "news community" after 1536, when tensions between Francis I of France and the Habsburg Emperor Charles V led to war. Jean L'Homme, an otherwise unknown publisher, began to print pamphlets with the latest diplomatic and political news. Between 1538 and 1544 he printed at least forty news pamphlets. The pamphlets appear to have been officially sanctioned and were fulsome in their praise of French victories, omitting mention of French reverses. After the war ended in 1544, the pamphlets ceased and Jean L'Homme and his press vanished; his imprints, like most cheap print, barely survive. ${ }^{68}$

Despite their ephemeral nature, pamphlets were uniquely important in reaching a wide readership, whereas most other news was closely guarded as privileged information by diplomats, merchants, and states. Their relatively cheap price, usually equivalent to a day's wages for a laborer, meant that they were theoretically affordable for most readers; peddlars diffused them within and far outside the cities, selling them alongside their other wares. The earliest and undoubtedly the most famous pamphlet polemicist was Martin Luther, who printed hundreds of pamphlets in just a few short years during the 1520s. Pamphlets even appealed to the illiterate. As Robert Scribner and others have described, their imagery made their rhetoric accessible to a public far broader than the reading

\footnotetext{
${ }^{68}$ Andrew Pettegree, "A Provincial News Community in Sixteenth-Century Europe," in Judith Pollmann and Andrew Spicer eds., Public Opinion and Changing Identities in the Early Modern Netherlands (Leiden: Brill, 2007), 33-48.
} 
minority. ${ }^{69}$ Pamphlets could also be read aloud, spreading their contents beyond those who could read themselves. The success of Luther's pamphlets (and of Catholic responses to them) had proven the marketability of the genre. So when religious controversy waned, printers produced pamphlets on prodigies of nature, such as comets, monstrous births and rains of daggers and blood, presented as warnings of divine wrath. ${ }^{70}$ Pamphlet wars regularly erupted in periods of political turmoil--for example in Paris in the 1590s (under the League) and during the regencies of the 17th century (1610-14 and the Fronde, 164853), in Venice during the Interdict 1606-7, and most spectacularly in England during the Civil War.

By the early 17 th century irregularly printed news-sheets had become routine in many western European cities. ${ }^{71}$ German post-masters, like scribes in Italy, began to release manuscript and print versions of important diplomatic information. This eventually led to the emergence of the first regular "newspaper" printed by Johann Carolus in Strasbourg. Carolus started by copying weekly avvisi for subscribers, but in 1605 he purchased "at a high and costly price" a printing press to produce more copies of his avvisi faster and more cheaply. ${ }^{72}$ The early newspaper thus grew directly out of the manuscript newsletter at a time (on the eve of the Thirty Years War) when political developments would soon affect large swaths of the population. Intellectuals had little to no role in the production of news information. The paper, published as a pamphlet of 8 pages, was not meant for opinion or ideas, but to apprise readers of current events; these

\footnotetext{
${ }^{69}$ Mark Edwards, Printing Propaganda, and Martin Luther (Berkeley: University of California Press, 1994); and Robert W. Scribner, For the Sake of the Simple Folk (New York: Cambridge University Press, 1981).

${ }^{70}$ Andre Pettegree, The Book in the Renaissance (New Haven, Conn: Yale University Press, 2010), chap. 7.

${ }^{71}$ For a summary of these observations see McCusker, "The Demise of Distance."

72 Johannes Weber, "Straßburg, 1605. The Origins of the Newspaper in Europe," German History 24:3 (2006): 387-412, p. 391-92.
} 
were typically described in a brief enumeration with no background explanation, although with a bias in favor of those in power locally. Because of the fragmentation of the German-language area, hundreds of newspapers were printed there during the seventeenth century. ${ }^{73}$

Newspapers next appeared in the Netherlands starting in 1618. Jan van Hilten's Courante was a single-sided broadsheet with two columns of text which grew to a double-sided sheet by 1620. In nearby Spanish-controlled Antwerp Abraham Verhoeven was especially prolific: his Nieuwe Tijdinghen appeared as a sequentially numbered pamphlet, with an illustrated title page, roughly three times per week, but lasted only 1620-29. Because of the Netherlands' position on many trade routes, the Dutch newspapers circulated more broadly than the German ones; for example, by 1665, Dutch news was being regularly translated in Moscow for the Tsar. ${ }^{74}$ Amsterdam and other Dutch cities produced newspapers for the various communities of exiles located there and scattered elsewhere --including French Ligueurs and dévôts, Anglican royalists during the Civil War, or English, Irish and Scottish Catholics. ${ }^{75}$ Although postpublication censorship existed in the Dutch Republic, it was exercised haphazardly and mostly on local political issues. ${ }^{76}$

When Dutch corantos translated into English started to enter the English market in 1620, English authorities granted a monopoly or license for one weekly newsbook to

\footnotetext{
73 Johannes Weber, "The Early German Newspaper - A medium of Contemporaneity," in Dooley, The Dissemination of News, 69-79; Pettegree, 182-87

${ }^{74}$ See Craig Harline, Pamphlets, Printing, and Political Culture in the Early Dutch Republic (Dordrecht: M. Nijhoff, 1987). On Dutch news in Moscow see: Ingrid Maier, "Zeventiende-eeuwse Nederlandse couranten vertaald voor de tsar," Tijdschrift voor Mediageschiendenis 1 (2009): 27-49.

${ }^{75}$ Paul Arblaster, From Ghent to Aix. How They Brought the News in the Habsburg Netherlands 1550-1700 (Leiden: Brill, 2014), 266

${ }^{76}$ Joris van Eijnatten. "Between Practice and Principle: Dutch Ideas on Censorship and Press Freedom, 1579-1795," Redescriptions Yearbook of Political Thought and Conceptual History 8 (2004), 1-29, 8.
} 
Nathaniel Butter and Nicholas Bourne who published the Corante, or newes from Italy, Germany, Spaine, and France in the 1620s in pamphlet form; the conditions of the license included submitting the text for approval prior to publication and making no reference to domestic affairs. ${ }^{77}$ In France a royal publication, Le Mercure français appeared sporadically as a large volume from 1613. The first weekly newspaper was licensed by the Crown in 1631-- the Gazette published by Théophraste Renaudot in Paris, with provincial editions, comprising mostly foreign news. In publishing a yearly compilation of the Gazette for 1631 (inviting a different kind of use from the initial serial publication, though no index was provided) Renaudot emphasized the practical utility of this information: "the merchant will no longer seek business in a besieged or ruined city, nor the soldier employment in countries where there is no war." ${ }^{78}$ In these and other monarchies, the early newspaper was tightly controlled by royal license and made no mention of local politics.

The exceptional breakdown of royal authority during the Civil War in England created the conditions for the appearance of partisan treatment of local news. Newsbooks started in November 1641 as weeklies, eight pages long, focused on domestic news. At first they reported on parliamentary proceedings, often transcribing speeches, but they soon became "bitter and aggressive instruments of literary and political faction," until Parliament regained control of the press in 1649 and licensed a limited number of them. During the 1650 s the Mercurius Politicus edited by Marchamont Nedham was the main source of domestic and foreign news, under government scrutiny. It was closed at the

\footnotetext{
${ }^{77}$ Pettegree, Invention of the News, 195.

${ }^{78}$ Théophraste Renaudot, Recueil des Gazettes de l'année 1631 (Paris: Bureau d'Adresse [Renaudot], 1632), preface, p. 5 (from Gallica consulted 7.2.14 ftp://ftp.bnf.fr/010/N0106358_PDF_1_-1DM.pdf)
} 
Restoration, when newsbooks became "fewer and more conservative. ${ }^{79}$ In 1666 the Oxford Gazette (later London Gazette) began what would be a 300-year-long run, starting in the format of a double-sided half-sheet printed on both sides; it began with an exclusive royal license, which was short-lived since the Licensing Act lapsed 1679-85 and permanently after 1695 . Among the new papers launched in 1695 were partisan papers like the Whig Flying Post and the Tory Post Boy whose names also suggested their distribution by post beyond London. ${ }^{80}$ The first daily newspaper, the Daily Courant, started in London in 1703 and around the same time the first newspapers in the English provinces (e.g. the Norwich Post, 1701, and the Bristol Post-Boy, 1702, though the earliest issues of these do not survive) and in the American colonies (Boston News-Letter, 1704). ${ }^{81}$

The market for newspapers was strong enough in England by 1712 that most of them survived the Stamp Act which required them to be printed on stamped paper at an extra cost of one half-penny per sheet; this means of raising revenue was also designed to keep the price of newspapers out of reach of the poorest members of society. English newspapers remained especially contentious, each in the sway of a party. Although advertisements provided an important revenue stream (also dented by the Stamp Act), newsmen were often paid a pension by a political party or figure. For example the Walpole administration controlled five newspapers in the 1740 s and by 1792 the government "had bought up half the press." ${ }^{82}$ Elsewhere in Europe newspaper

\footnotetext{
${ }^{79}$ Joad Raymond, The invention of the newspaper. English newsbooks 1641-49 (Oxford; Clarendon, 1996), 13-15.

${ }^{80}$ Pettegree, Invention, 245 and on early forms of the penny post 243-44.

${ }^{81}$ G.A. Cranfield, The Development of the Provincial Newspaper 1700-1760 (Westport CT: Greenwood Press, 1962), 13; Hugh Amory and David D. Hall eds., A History of the Book in America, vol. 5: The Colonial Book in the Atlantic World (Chapel Hill: University of North Carolina Press, 2007), chaps. 8-10. ${ }^{82}$ Pettegree, 247-48, 268, 306, 368.
} 
monopolies were more prevalent, limiting the editors' ability to engage in political commentary; in many places newspapers continued to offer mainly foreign news and nothing to challenge the local authorities. Political debate happened instead (if at all) in pamphlets and other periodicals, such as weekly or monthly journals of political analysis. ${ }^{83}$ Given the constraints on print, the manuscript newsletter was valued as a medium that allowed freer (also customized and sometimes speedier) articulation of news and opinion, both in contexts where the press was controlled tightly (e.g. France, Rome) and also where it was less so (England). ${ }^{84}$ Manuscript newsletters could also serve as agents of disinformation, as in the case of the circulation of false reports of a plan by Charles I to reform the government. ${ }^{85}$ Of course both print and manuscript also fueled the oral exchange of news and rumor in all kinds of venues, from the home to the marketplace, the coffeehouse to the salon.

Historians have variously portrayed the newspaper as an agent of liberation from the ancien régime through the creation of a public sphere (following Jürgen Habermas for example) or by contrast have emphasized the control of news by those in power. Others have reflected on how the newspaper may have encouraged new concepts of time and space, making the European continent seem smaller, and creating an awareness of the simultaneous experience of one event in many different places. ${ }^{86}$ With the spread of

\footnotetext{
${ }^{83}$ Pettegree, 284. For a bibliography of French periodicals see Jean Sgard ed. Dictionnaire de la presse: I, Dictionnaire des journaux, 1600-1789, 2 vols. (Paris: Universitas; Oxford: Voltaire Foundation, 1991), available online at http://c18.net/dp/index.php.

${ }^{84}$ See Alex W. Barber, 'It is Not Easy What to Say of our Condition, Much Less to Write It': The Continued Importance of Scribal News in the Early 18th Century', Parliamentary History 32:2 (2013): 293-316; Brendan Dooley, "De bonne main: les pourvoyeurs de nouvelles à Rome au XVIIe sicle," Annales 54:6 (1999): 1317-44; Robert Darnton, "An Early Information Society," 4-9.

${ }^{85}$ Noah Millstone, "Evil Counsel: the Propositions to Bridle the Impertinency of Parliament and the Critique of Caroline Government in the Late 1620s," The Journal of British Studies 50:4 (2011): 813-839.

${ }^{86}$ For this argument, see Daniel Woolf, "News in Early Modern England," in Dooley ed., The

Dissemination of News, 80-118, pp. 82-86.
} 
European business and imperial interests around the globe both East and West, European information and news networks began to encompass - and eventually define - the rest of the globe. Perhaps no event better illustrates the expansion of European information networks better than accounts of the Ming-Qing conflict. The fall of Beijing in 1644 and the subsequent consolidation of Manchu control over the former territories of the Ming empire was a global drama that unfolded across diverse media, leading Sven Trakulhun to dub the event as a critical moment in Europe's "media revolution." ${ }^{, 87}$ Almost immediately after the sack of Beijing in 1644, the Dutch in Nagasaki, Formosa, and Batavia learned about the war in China and sent information to the Council of Seventeen in Amsterdam. The Jesuits were more directly involved in the human drama of the conquest, often as direct witnesses to the history unfolding around them. By 1647 the event was known in Europe, when the English newspaper Moderate Intelligencer proclaimed that China was now "another Germany ruined, two places that exceeded the world, and this is the wretched fruit of that thing called War..."88 Other updates soon followed, but none had the impact of Martino Martini's S.J. De bello tartarico historia, first printed in Antwerp in 1654, then in over twenty editions in most European vernaculars. The collapse of the Ming became a popular topic in literature, inspiring a handful of German romances and plays in Dutch and English. Much was written on the conflict and its implication for both trade and the fate of the Chinese. By the 1640s, information networks had developed fully enough for Europeans to "virtually witness"

\footnotetext{
${ }^{87}$ Seven Trakulhun, "Das Ende der Ming-Dynastie in China (1644). Eine 'große Revolution' und ihre mediale Gestaltung in Europa," in Sven Grammp ed., Revolutionsmedien, Medienrevolutionen (Konstanz: UVK Verlagsgesellschaft, 2008), 475-508; also Edwin J. Van Kley, "News from China; SeventeenthCentury European Notices of the Manchu Conquest." The Journal of Modern History. 45:4 (1973): 561582.

${ }^{88}$ Moderate Intelligencer 128 (August 26, 1647- September 2, 1647), unpaginated, in The 17th and 18th Century Burney Collection Newspapers. Consulted on-line 6 October 2013.
} 
the world around them. Events in China became current events, defining part of what educated Europeans would have recognized as history in the making. Whether or not that seemed revolutionary to them is difficult to ascertain.

The growth of information in so many different areas of life, in different media and genres, between 15 th and 18 th centuries, resulted in new challenges in managing large accumulations of manuscript and printed material and in assessing contradictory reports, analyses, and conclusions. Critical judgment, which humanist education was designed to cultivate in the offspring of the elite through the study of classical culture at the beginning of the period, became a skill that a much broader range of the European population put in practice, in making sense of the contradictions made visible in confronting multiple news sources, or the reports from faraway places which surprised expectations. Considering this period through the lens of an "information revolution" which affected the production, distribution, and consumption of information offers a new lens through which to examine more familiar developments of the period, including printing, state-building, commercial, and imperial growth and the rise of a public sphere.

Further Reading:

Jeremy Black. A History of Diplomacy. London: Reaktion, 2010.

Jeremy Black. The Power of Knowledge: How Information and Technology Made

the Modern World. New Haven: Yale University Press, 2014.

Peter Burke. A Social History of Knowledge: from Gutenberg to Diderot.

Camibrdge: Polity Press, 2000. 
Simon F. Davies and Puck Fletcher eds. News in Early Modern Europe. Currents and Connections. Leiden: Brill, 2014.

James Delbourgo and Staffan Müller-Wille eds. "Listmania," a Focus section in Isis 103:4 (2012): 710-52.

Markman Ellis. The Coffee House. A Cultural History. London. Weidenfeld and Nicolson, 2004.

Peter Howlett and Mary Morgan eds. How Well Do Facts Travel: the dissemination of reliable knowledge. Cambridge: Cambridge University Press, 2011.

Carl Kaestle ed. Special Issue on the History of Literacy, History of Education Quarterly 30:4 (1990).

Clé Lesger. The Rise of the Amsterdam Market and Information Exchange: Merchants, Commercial Expansion and Change in the Spatial Economy of the Low Countries, C. 1550-1630. Aldershot: Ashgate, 2006.

John C. Rule and Ben S. Trotter. A World of Paper: Louis XIV, Colbert de Torcy and the Rise of the Information State. Montreal: McGill-Queens University Press, 2014.

C. J. Sommerville, The News Revolution in England: Cultural Dynamics of Daily Information. New York: Oxford University Press, 1996.

Tom Standage. Writing on the wall: social media, the first 2,000 years. London, New York: Bloomsbury, 2013. 